\title{
Inulinase Production Capability of a Promising Medicinal Plant: Inula viscosa
}

\author{
Özden CANLI TAŞAR*
}

\begin{abstract}
High Technology Application and Research Centre, Erzurum Technical University Erzurum, TURKEY ORCID ID: Özden CANLI TAŞAR: https://orcid.org/0000-0002-4313-5373
\end{abstract}

\begin{abstract}
Received: 03.06.2020
Accepted: 23.06 .2020

Published online: 28.06 .2020

Issue published: 29.06 .2020

Abstract: The present study was designed to examine the inulinase production capability of Rhodotorula glutinis SO-28 by using Inula viscosa, a promising medicinal plant, as sole carbon source in submerged fermentation. Inula viscosa, a perennial member of Asteraceae family, is a popular and widespread medicinal plant in the Mediterranean region. It is termed as "yapışkan andiz otu" in Turkey and has been widely used in folk medicine since the ancient times. Taguchi design of experiment (DOE) technique was utilized for the inulinase production optimization process. An orthogonal array layout of L16 was utilized with four influential factors as following: Inula viscosa amount, agitation speed, incubation temperature, and incubation time at four levels. The obtained results showed that optimized inulinase production enhanced enzyme activity as $99.63 \mathrm{U} / \mathrm{ml}$ which was 5-fold higher than the unoptimized condition. In brief, Inula viscosa can be used effectively for inulinase production and use of statistical optimization techniques like Taguchi DOE significantly increases the enzyme yield.
\end{abstract}

Keywords: Dittrichia viscosa, enzyme, Rhodotorula glutinis, Taguchi DOE.

\section{Umut verici bir tıbbi bitkinin inulinaz üretim kapasitesi: Inula viscosa}

\begin{abstract}
Öz: Bu çalışma, batık kültür fermantasyonunda tek karbon kaynağı olarak umut verici bir tıbbi bitki olan Inula viscosa kullanılarak Rhodotorula glutinis SO-28'in inulinaz üretim kapasitesini incelemek üzere tasarlanmıştır. Asteraceae familyasının çok yıllık bir üyesi olan Inula viscosa, Akdeniz bölgesinde popüler ve yaygın bir tıbbi bitkidir. Türkiye'de "yapışkan andız otu" olarak adlandırılmakta ve eski çağlardan beri halk tıbbında yaygın olarak kullanılmaktadır. İnülinaz üretim optimizasyonu sürecinde Taguchi deney tasarımı (DOE) tekniği kullanılmıştır. Inula viscosa miktarı, çalkalama hızı, inkübasyon sıcaklığı ve inkübasyon süresi olmak üzere dört etkin faktörlü ve dört seviyeli olan L16 ortogonal dizilim kullanılmıştır. Elde edilen sonuçlar, optimize edilmiş inulinaz üretiminin enzim aktivitesini, optimize edilmemiş durumdan 5 kat daha yüksek olan 99.63 U / ml olarak arttırdığını göstermiştir. Kısacası Inula viscosa, inülinaz üretiminde etkin bir şekilde kullanılabilir ve Taguchi DOE gibi istatistiksel optimizasyon tekniklerinin kullanımı enzim verimini azımsanmayacak ölçüde artırmaktadır.
\end{abstract}

Anahtar kelimeler: Dittrichia viscosa, Enzim, Rhodotorula glutinis, Taguchi DOE.

\section{Introduction}

In ancient times, people used to cure their diseases by using medicinal plants as the chemicals were not manufactured in labs. There are many active ingredients derived from plants for production of drugs and medicines and these ingredients are less poisonous and have fewer side effects than the synthetic drugs (Seca, Grigore, Pinto, \& Silva, 2014). Asteraceae family includes many different kinds of aromatic plants in different habitats as tropics, cold arctic, or alpines countries (Aissa et al., 2019); besides, some of the members (Inula racemosa) of this family are used in Ayurveda in India (Kalachaveedu, Raghavan, Telapolu, Kuruvilla, \& Kedike, 2018; Mangathayaru, Kuruvilla, Balakrishna, \& Venkhatesh, 2009). An Asteraceae family member, the genus Inula, has almost 100 species worldwide and many of the species have important facilities such as bactericidal, antidiabetic, and anti-inflammatory effects (Gokbulut, 2013). Inula viscosa (L.) Aiton (syn. Dittrichia viscosa (L.) Greuter), a perennial member of Asteraceae, is a popular and widespread medicinal plant in the Mediterranean region, especially in Turkey, Middle East, Bulgaria, Portugal, and Spain (Al-Dissi, 2001; Al-Eisawi, 1998; Baytop, 1984). Inula viscosa has different names as 'false yellowhead, sticky fleabane, Magramane (in Algeria), aromatic inula, yapışkan andız otu, and kanser otu (cancer weed) (in Turkey)' (Gueribis et al., 2019; Ozkan, 2019). Inula viscosa contains many important bioactive compounds such as sesquiterpenes, sesquiterpene acids, flavonoids, azulenes, costic acids, and essential oils; besides, Inula viscosa has high amounts of phenolic compounds that contribute to the overall antioxidant potential of the plants. Therefore, this plant is frequently used to control or inhibit symptoms of health problems (Al-Dissi, 2001; Al-Qura'n, 2009; Benbacer, 2012; Danino, 2009; Gokbulut, 2013; Ozkan, 2019; Seca et al., 2014; Zeggwagh, Ouahidi, Lemhadri, \& Eddouks, 2006). Inula viscosa has been widely used for therapeutic purposes in folk medicine because of its anti-inflammatory, antipyretic, antioxidant, antimicrobial, antiseptic, antiphlogistic, anthelmintic, balsamic, expectorant, diuretic, anti-anemic, and muscle relaxant activities (AlDissi, 2001; Al-Qura'n, 2009; Ali-Shtayeh, 2000; Barbetti, 1985; Baytop, 1984; Lauro, 1990; Ozkan, 2019; Zeggwagh et al., 2006). In Jordan, Inula viscosa is prescribed as a promoter agent in the induction of abortion and female sterility (Al-Dissi, 2001; Karim, 1990). Inula viscosa is used in drug production for the treatment of diabetes, cancer, hypertension, tuberculosis, infertility, lung and gastro- 
duodenal disorders, wounds, and skin diseases (Beyranvand et al., 2018; Dor, 2012; Orhan, Gökbulut, \& Deliorman Orhan, 2017; Ozkan, 2019; Zeggwagh et al., 2006). Inula viscosa has a great anti-ulcerogenic effect. A recent paper showed that ethanol-extracted Inula viscosa was the most effective plant after Quercus coccifera and Punica granatum and it showed no ulcers on the ethanolinduced gastric damage in rats. Additionally, when the petechial lesions were ranked in terms of ethanolic extract of IV was the most effective plant among all these plant extracts (Alkofahi, 1999; Amin, 2013). Colorectal cancer is the second most common cancer in females and the third in males worldwide and it was obtained that Inula viscosa has reduced cell viability, induced apoptosis, and inhibited tumor growth in mice; additionally, no side effects such as weight loss, behavior changes and changes in kidney and liver functions were observed (Bar-Shalom et al., 2019). The oily paste extracts of Inula viscosa leaves (major compounds tomentosin and costic acid) has fungicidal effects on downy mildew formation in detached leaf tissues of grapes (Cohen, 2006; Seca et al., 2014).

Inulin is a major carbohydrate reserve material in the roots and tubers of some plants such as onion, garlic, leek, and etc. Inulin consists of linear chains of $\beta$-2,1-linked Dfructofuranose residue through a sucrose-type linkage at the reducing end (Canli \& Kurbanoglu, 2012; Chi, Chi, Zhang, Liu, \& Yue, 2009; Tasar, Erdal, \& Algur, 2015; Xiong, Jinhua, \& Dongsheng, 2007). Inulinase (2,1- $\beta$-Dfructan fructanohydrolase, EC 3.2.1.7) is an important enzyme that catalyzes removal of the terminal fructose residues from the non-reducing end of the inulin molecule (Chi et al., 2009). Fructose plays a considerable role in food industry due to its higher sweetening capacity with low calories for diabetics, prevention of the colon cancer, increment property of iron absorption in children, and on the like (Chen, 2009; Chi et al., 2009; Singh, Dhaliwal, Puri, 2006; Tasar et al., 2015). Inulinase is an inducible enzyme and inulin-rich feed stocks as leek, onion, Jerusalem artichoke, dahlia, asparagus, etc. can be used for substrate and inducer for inulinase production (Canli \& Kurbanoglu, 2012; Erdal, 2011; Singh, Chauhan, Kaur, \& Pandey, 2020; Singh, Dhaliwal, Puri, 2006).

The demand for fermentation process statistical optimization techniques has been increasing day by day due to its higher performance for yield enhancement with lower human power and production cost. Many prior studies were made by using classical "one variable at a time" approach for optimization of the fermentation process (Aydogan, Taskin, Canli, Arslan, \& Ortucu, 2014; Canli \& Kurbanoglu, 2011, 2012; Taskin, Erdal, \& Canli, 2010; Taskin et al., 2016). This method is usually used for specific requirements for growth and product formation by adding or subtracting some components from the medium with minimal complicated medium interactions. On the other hand, statistical optimization techniques such as response surface methodology, Box-Behnken design, Plackett-Burman design, and Taguchi design allow quick screening of large experimental domain and reflect the role of each of the components (Farid, Ghoneimy, El-Khawaga, Negm-Eldein, \& Awad, 2013). The Taguchi-based optimization technique has produced a unique and powerful optimization discipline that differs from traditional practices and it is used for maximizing robustness of products and processes with high quality at low cost and less labor (Kıvak, 2014; Phadke, 1989; Rao, 2008). In Turkey, also in many different countries in the world, people used to consume the Inula viscosa without any extraction method as they usually consume it as a herbal tea in folk medicine.

Autoclave-based extraction of the plants was used before (Deng et al., 2019; Passos et al., 2006). The autoclave was employed for the sterilization process of the medium and; thus, partially extraction of the Inula viscosa leaves was used in this study. Inulinase production was researched by using different microorganisms and substrates previously (Canli, Tasar, \& Taskin, 2013; Chaturvedi, Bhattacharya, Nain, Prasanna, \& Khare, 2019; Erdal, 2011; Tasar et al., 2015; Xiong et al., 2007) but, to the best of our knowledge, there is not any report about inulinase production by Rhodotorula glutinis with using the Inula viscosa as substrate. The aim of this study was to research the ability of Inula viscosa as a novel carbon source for inulinase production without any further extraction process.

\section{Materials and Methods}

All chemicals were purchased from Sigma Chemical Co. (St. Louis, MO, USA) and Merck (Darmstadt, Germany). Inula viscosa was purchased from local markets as herbal tea (Black Natural, Fitofarma Corp., Istanbul, Turkey). Rhodotorula glutinis SO-28 (GenBank accession number KX017572) was obtained from our laboratory (YUTAM, Erzurum, Turkey) culture collection. The cultures were maintained on potato dextrose agar slants at $4{ }^{\circ} \mathrm{C}$ and recultured bimonthly. To prepare the yeast starter, 250-ml Erlenmeyer flasks containing $100 \mathrm{ml}$ of potato dextrose broth was inoculated with one loopful of a 24-hr-old culture of culture of yeast grown on potato dextrose agar and then incubated at $30^{\circ} \mathrm{C}$ and $200 \mathrm{rpm}$ for $48 \mathrm{hr}$ on an orbital shaking incubator (Zhicheng ZHWY- 200B, China). After growth, the yeast cells were collected by centrifugation at $5000 \times \mathrm{g}$ for $20 \mathrm{~min}$ and resuspended in sterile saline water. The final cell concentration was adjusted to $10^{6}$ cells $/ \mathrm{ml}$. The initial fermentation medium was composed as follows (g/l): 10 Inula viscosa, $1 \mathrm{KH}_{2} \mathrm{PO}_{4}$, 3 bacterial peptone, $0,5 \mathrm{KCl}, 0,5 \mathrm{MgSO}_{4} .7 \mathrm{H}_{2} \mathrm{O}, 1,5$ $\mathrm{NH}_{4} \mathrm{NO}_{3}, 0,2 \mathrm{CaCl}_{2}, 0,2 \mathrm{NaCl}$. The unoptimized fermentation medium was run at $30^{\circ} \mathrm{C}$ at $100 \mathrm{rpm}$ for $24 \mathrm{hr}$. All the experiments were run at $250 \mathrm{ml}$ - Erlenmeyer flasks including $50 \mathrm{ml}$ medium and initial $\mathrm{pH}$ was adjusted to 6.0 with $1 \mathrm{~N} \mathrm{NaOH}$ or $1 \mathrm{~N} \mathrm{HCl}$ and autoclaved at $121^{\circ} \mathrm{C}$ for 20 min. This step was for both of partially extraction of Inula viscosa and sterilization of the medium. The flasks were cooled to room temperature and $0,5 \mathrm{ml}$ of yeast cell suspension was transferred as inoculum material into each flask.

\subsection{Taguchi DOE methodology}

Higher yield and less production cost are the main factors for industrial production process. For this purpose, researchers apply effective optimization techniques in process engineering. The fundamentals of these techniques are the full factorial design and fractional factorial design (Tan, 2005). The full factorial design needs all of the factors at each level but if the experiments do not include a few factors, this technique cannot be applied due to numerous runs. In this context, Dr. Genichi Taguchi developed a powerful optimization process, namely 
Taguchi design of experiment (DOE) method, that caused the recovery of the national economy in a short time in Japan after the World War II. This method has enabled the results to be standardized and easy to apply by the researchers. Taguchi method includes standard tables known as orthogonal arrays (OA) for the design of the experiments. Table 2 shows an OA that consists of four factors with four levels, which were effective for inulinase production by Rhodotorula glutinis SO-28, with the symbol of $\mathrm{L}_{16}$. A traditional full factorial design needs $4^{4}$ (four levels with four factors) experiments that are impossible to run; however, Taguchi method suggests only 16 experiments (a fraction of the full factorial design) for optimization. Fewer experiments mean less human power and energy consumption and; therefore, Taguchi method enables a powerful optimization process (Ozden Canli Tasar, 2017). Taguchi DOE methodology also uses interactions between the parameters on some arrays (e.g. $\mathrm{L}_{9}$ ) but not on $\mathrm{L}_{16}$ orthogonal array due to the multiplicity of the factors. Recent papers indicated that Taguchi DOE does not account for interaction between the parameters in order to get cost-effective optimization process; consequently, these interactions can be neglected (Tan, 2005; Canli Tasar, 2017). Taguchi DOE methodology includes controllable and uncontrollable variables (Alhaddad, Cabibihan, Hayek, \& Bonarini, 2019; Mori, 2011). This method uses the $\mathrm{S} / \mathrm{N}$ ratio (signal-to-noise, unit: $\mathrm{dB}$ ) for performance characteristics instead of the average value to interpret the results into a value for characteristics evaluation in the optimal setting analysis (Tan, 2005). This method is based on three different characteristic categories as the larger-the better, the nominal-the better and the smaller-the better. The aim of this study was to increase the inulinase production. Hence, the larger-the better criterion for the signal-to-noise ratios was used as the quality characteristic for the evaluation of the experimental results was used and the equation is shown below:

$\mathrm{S} / \mathrm{N}=-10 \log _{10}\left(1 / \mathrm{n} \sum_{i=1}^{n} 1 / Y i^{2}\right)$

where $\mathrm{S} / \mathrm{N}$ are performance statistics, defined as the $\mathrm{S} / \mathrm{N}$, $n$ the number of repetitions for an experimental combination, and $\mathrm{Y} i$ is a performance value of the $i$ th experiment. $\mathrm{S} / \mathrm{N}$ ratio was formulated to obtain the selection of the highest result by the designer (Jean \& Tzeng, 2013). Use of Inula viscosa as substrate for inulinase production was affected from Inula viscosa amount (g/l) and some environmental conditions like agitation speed (rpm), incubation temperature $\left({ }^{\circ} \mathrm{C}\right)$, and incubation time (h) with four levels were researched in the current study (Table 1).

Table 1. Selected culture conditions and assigned levels.

\begin{tabular}{llllll}
\hline \multirow{2}{*}{ Serial no. } & \multirow{2}{*}{ Factor } & \multicolumn{2}{l}{ Level } & & \\
\cline { 3 - 6 } & & 1 & 2 & 3 & 4 \\
\hline 1 & Inula viscosa $(\mathrm{g} / \mathrm{l})$ & 10 & 20 & 30 & 40 \\
2 & Agitation $(\mathrm{rpm})$ & 100 & 150 & 200 & 250 \\
3 & Temperature $\left({ }^{\circ} \mathrm{C}\right)$ & 30 & 32.5 & 35 & 37.5 \\
4 & Time $(\mathrm{h})$ & 24 & 48 & 72 & 96 \\
\hline
\end{tabular}

2.2. Enzyme assay

The extracellular inulinase activity was determined as the crude-enzyme activity in culture filtrate with some modification (Burkert et al., 2006). One exo-inulinase unit is defined as the amount of enzyme produced $1 \mu$ mole of glucose per minute under standard assay conditions.
Culture medium was centrifuged at $5000 \mathrm{rpm}$ for $15 \mathrm{~min}$ and supernatant was used as inulinase source. Reaction mixture consists of $0.1 \mathrm{ml}$ enzyme extract and $0.9 \mathrm{ml}$ of 0.1 $\mathrm{M}$ sodium acetate buffer ( $\mathrm{pH} 5.5$ ) containing $2 \%$ inulin $(\mathrm{w} / \mathrm{v})$ and this was placed in glass test tubes and incubated at $50^{\circ} \mathrm{C}$ for $15 \mathrm{~min}$. The reaction mixture was then assayed for glucose as a reducing sugar using DNS method (Miller, 1959). Thus, $1 \mathrm{ml}$ of DNS reagent was added to each test tube and then put in the boiling water bath for $10 \mathrm{~min}$. After cooling to room temperature, the volume of the glass tubes was raised to $8 \mathrm{ml}$ with distilled water. A spectrophotometer (Thermo MultiSkan Go, Finland) was used to determine the percentage of transmittance at 592 $\mathrm{nm}$.

\subsection{Analysis of variance}

The analysis of variance (ANOVA) of the obtained experimental results was calculated to indicate the quality characteristics variation using the obtained parameters. The most effective factors had the greatest impact on the inulinase production and all of these parameters were controlled carefully. Minitab® 19.1.1 Statistical Software (United States) was employed both of Taguchi DOE and ANOVA analysis. All of the experiments were run three times with two parallels and the results were taken as averages.

\section{Results and Discussion}

Taguchi DOE uses mathematical and statistical tools for the formulation of the medium and the other environmental conditions. In the current study, Taguchi DOE method was utilized for inulinase production by Rhodotorula glutinis SO-28 using Inula viscosa as sole carbon source. Inula viscosa has a great potential for treating many disorders due to its effective compounds. The results showed that inulinase production and $S / N$ ratios had a great variation correlated to each experimental design with the larger-the better quality character (Table 2).

$\mathrm{S} / \mathrm{N}$ ratio determines the deviation of the quality characteristics from the obtained results (Sharma, Verma, Sidhu, \& Pandey, 2005; 2006, Taskin et al., 2013). The minimization of the noise factor ensures higher enzyme production and; in addition, it decreases the undesirable effects. The lowest inulinase activity $(1.10 \mathrm{U} / \mathrm{ml})$ was obtained from $16^{\text {th }}$ experimental design and; therefore, the lowest S/N ratio was obtained from the same experimental design. On the other hand, the highest enzyme activity $(93.61 \mathrm{U} / \mathrm{ml})$ was carried out using the $10^{\text {th }}$ experimental design and; in accordance with this, the highest $\mathrm{S} / \mathrm{N}$ ratio was obtained from the same experimental design.

Response data for $\mathrm{S} / \mathrm{N}$ ratios and their comparison were given in Table 3. Delta value is the difference between the maximum and minimum average response (signal-to-noise ratio or standard deviation) for the factor and the rank is the rank of each Delta where Rank 1 is the largest Delta. The ranking in Table 3 demonstrates that incubation temperature and incubation time had relatively strong impacts on the inulinase production while Inula viscosa amount and agitation speed had relatively weak impacts. The analysis of variance (ANOVA) confirmed the ranking made on the basis of the amplitude of $\mathrm{S} / \mathrm{N}$ ratio variation (Table 4$)$. 
Table 2. Taguchi L16 orthogonal array, inulinase activity $(\mathrm{U} / \mathrm{ml})$ and $\mathrm{S} / \mathrm{N}$ ratios.

\begin{tabular}{llllll}
\hline Exp. no. & Inula viscosa & Agitation & Temperature & Time & Inulinase $(\mathrm{U} / \mathrm{ml})^{\mathrm{a}}$ \\
\hline 1 & 1 & 1 & 1 & 1 & $18.36 \pm 1.23$ \\
2 & 1 & 2 & 2 & 2 & $28.47 \pm 1.21$ \\
3 & 1 & 3 & 3 & 3 & $41.79 \pm 1.14$ \\
4 & 1 & 4 & 4 & 4 & $79.23 \pm 1.71$ \\
5 & 2 & 1 & 2 & 3 & $41.33 \pm 1.13$ \\
6 & 2 & 2 & 1 & 4 & $2.68 \pm 0.17$ \\
7 & 2 & 3 & 4 & 1 & $67.77 \pm 1.33$ \\
8 & 2 & 4 & 3 & 2 & $88.07 \pm 2.65$ \\
9 & 3 & 1 & 32.0865 & 37.9742 \\
10 & 3 & 2 & 4 & 3 & $93.13 \pm 0.18$ \\
11 & 3 & 3 & 1 & 2 & $63.61 \pm 2.45$ \\
12 & 3 & 4 & 2 & 1 & $1.44 \pm 0.15$ \\
13 & 4 & 1 & 4 & 2 & $45.80 \pm 2.57$ \\
14 & 4 & 2 & 3 & 1 & $36.61 \pm 1.12$ \\
15 & 4 & 3 & 2 & 4 & $35.22 \pm 1.35$ \\
16 & 4 & 4 & 1 & 3 & 38.35 \\
\end{tabular}

aValues mean \pm standard deviation $(\mathrm{SD})$.

Table 3. Response table for $\mathrm{S} / \mathrm{N}$ ratios and their comparison. ${ }^{*}$

\begin{tabular}{lllll}
\hline Level & Inula viscosa & Agitation & Temperature & Time \\
\hline 1 & 31.19 & 22.77 & 17.78 & 24.09 \\
2 & 29.10 & 27.09 & 23.89 & 34.41 \\
3 & 19.82 & 34.10 & 25.71 & 26.26 \\
4 & 24.07 & 20.23 & 36.81 & 19.44 \\
Delta & 11.37 & 13.87 & 19.03 & 14.97 \\
Rank & 4 & 3 & 1 & 2 \\
\hline
\end{tabular}

* Larger is better

Table 4. Analysis of variance for means.

\begin{tabular}{lllllll}
\hline Source & DF & Seq SS & Contribution (\%) & Adj SS & Adj MS & F \\
\hline Inula viscosa & 3 & 835.0 & 5.68 & 835.0 & 278.3 & 0.18 \\
Agitation & 3 & 1384.9 & 9.39 & 1384.9 & 461.6 & 0.901 \\
Temperature & 3 & 6004.6 & 40.65 & 6004.6 & 2001.5 & 1.33 \\
Time & 3 & 2008.0 & 13.65 & 2008.0 & 669.3 & 0.822 \\
Residual Error & 3 & 4530.6 & 30.63 & 4530.6 & 1510.2 \\
Total & 15 & 14763.1 & 100 & & & 0.74 \\
\end{tabular}

DF: Degree of freedom; Seq SS: Sequential sum of square; Adj SS: Adjusted sum of square; Adj MS: Adjusted mean of squares; F: F value; P: P value.

The percentage contribution indicates the individual contribution of each factor on the mean response and was calculated using sequential sum of square of a factor to the total sequential sum of square (Fig. 1). The highest contribution was provided by the temperature factor and the time factor, respectively. Inula viscosa, the carbon source of the medium, had the least effect and the incubation temperature factor was the most powerful factor among all of the other factors.

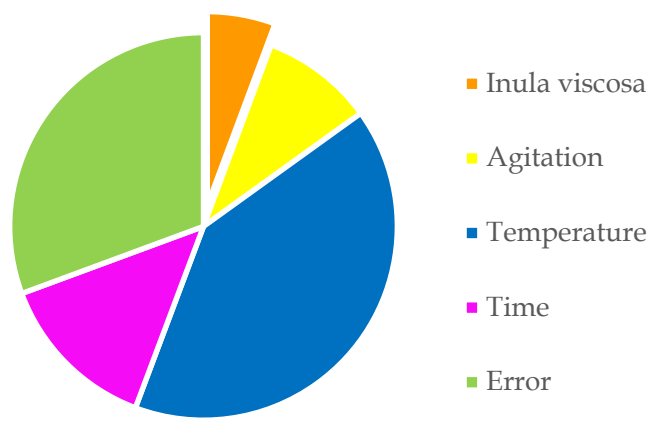

Figure 1. Contribution of factors on inulinase production

The calculated $\mathrm{F}$ values confirmed that the most significant influencing factor for inulinase production was incubation temperature (Table 4). The next significant factors, in the order of their relative influences, were incubation time > agitation speed > Inula viscosa amount, respectively. The importance of the environmental conditions for enzyme production was reported before (Canli \& Kurbanoglu, 2011; Mandal, 2015; Tasar, 2017; Taskin et al., 2016). In a recent paper about utilization of the leek as the substrate for inulinase production, leek amount had the greatest contribution among all the other factors (Tasar et al., 2015). However, in a different previous study about production of $\beta$-fructofuranosidase by Rhodotorula glutinis, time factor had the greatest effect among all other parameters and the sugar beet powder, the substrate which was used as carbon source in the study, had less effect than time factor while the percentage contribution of the temperature factor was found fewer than the sugar beet powder (Tasar, 2017). On the contrary of this result, it was reported that leek powder, the substrate that was selected as carbon source, was the most powerful factor while the time factor had the least effect among all the other factors for inulinase production by Rhodotorula glutinis (Tasar et al., 2015). These results might be originated from the structural difference of the carbon sources and the response of the microorganisms to the medium ingredients and other environmental conditions.

Inulinase production by the microorganisms were carried out using different substrates before such as leek (Allium ampeloprasum var. porrum) (Canli \& Kurbanoglu, 2012; Tasar et al., 2015), Jerusalem artichoke (Helianthus tuberosus) (Erdal, 2011), Asparagus racemosus (Singh, 
Dhaliwal, Puri, 2006), agro-industrial residues (Sguarezi, 2009), and garlic (Allium sativum) (Sharma, Kainth, \& Gill, 2006). However, to the best of our knowledge, there is not any report about inulinase production using any Inula sp. as carbon source. Inula viscosa flowers, leaves, and roots can be consumed as raw or cooked food in Turkey (Ertuğ, 2014). Recent studies showed that different parts of Inula viscosa had higher antioxidant activities when extracted with water and less antioxidant activity was carried out by methanol extract using both of the DPPH radical scavenging and ABTS assays (Gokbulut, 2013).
For prediction analysis of Taguchi DOE, the main effect plot was utilized (Fig. 2). Taguchi DOE proposed a new design for the factors using the optimal levels (Table 5). For validation analysis, the proposed experimental methodology, inulinase production was performed using the optimum level of each individual factor of Taguchi prediction. The obtained data from the proposed design $(99.63 \pm 1.20 \mathrm{U} / \mathrm{ml})$ was close to the predicted value $(101.80$ $\pm 2.11 \mathrm{U} / \mathrm{ml}$ ) and; thus, the statistical evaluation was validated. Besides, the experimental result was 5 -fold higher than the unoptimized condition $(18.36 \pm 1.23 \mathrm{U} / \mathrm{ml})$.

Table 5. Proposed optimal levels of each individual factors.

\begin{tabular}{lllll}
\hline & Inula viscosa & Agitation & Temperature & Time \\
\hline Level & 1 & 3 & 4 & 2 \\
Optimal condition & 10 & 200 & 37.5 & 48 \\
\hline
\end{tabular}

Main Effects Plot for SN ratios Data Means

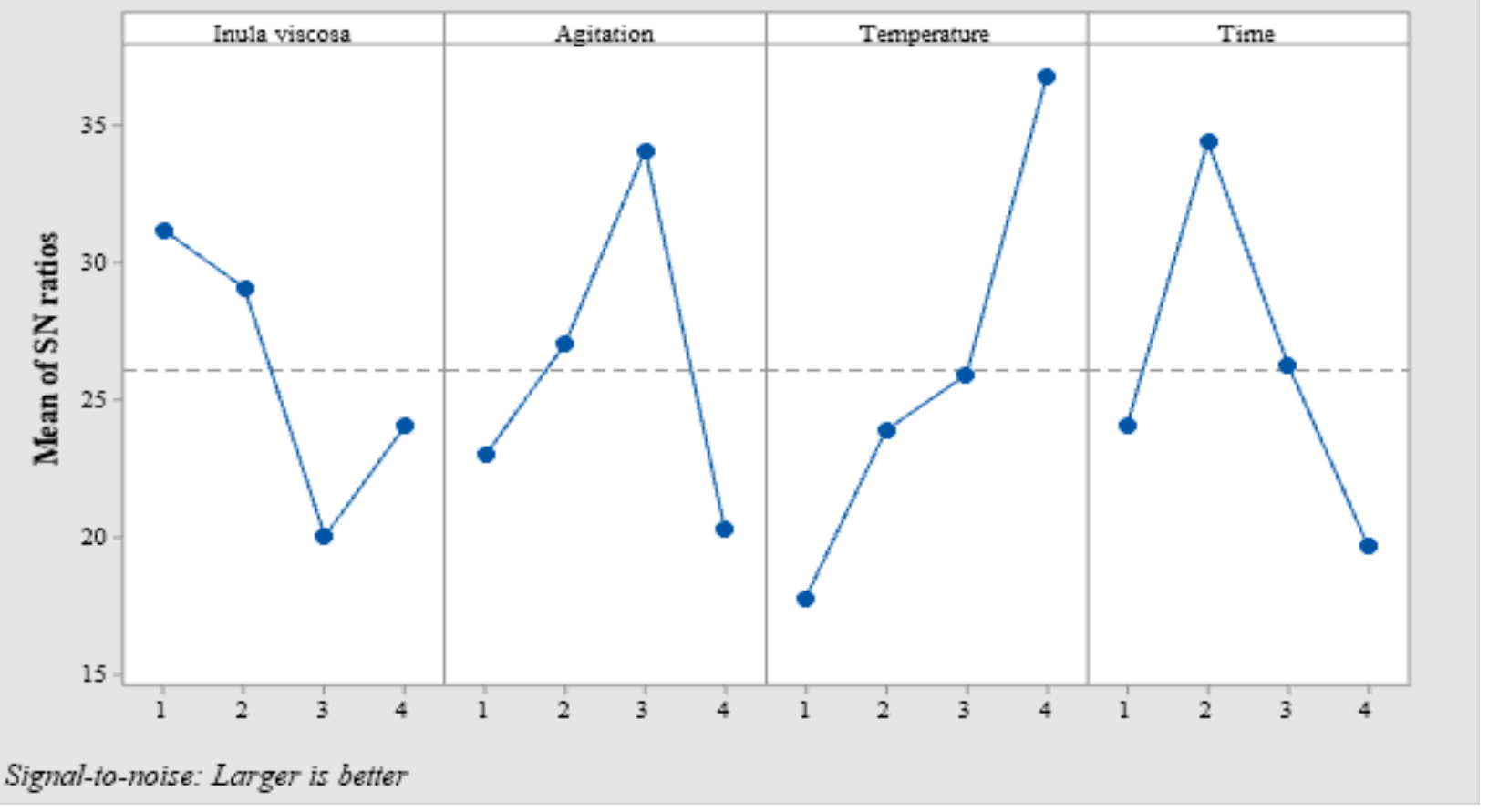

Figure 2. Main effects plot of $\mathrm{S} / \mathrm{N}$ ratios

\section{Conclusions}

Inula viscosa is an important and promising plant in folk medicine. It has many benefits on human health and treatment of many diseases such as, cancer, diabetes, infertility, and etc. Inulinase is an industrially important enzyme and has been widely used. Taguchi DOE method was successfully employed for inulinase production by Rhodotorula glutinis using Inula viscosa as sole carbon source in the current study. The experimental results showed that Inula viscosa has a great potential for inulinase production. This study evaluates that the substrate choice and environmental conditions may affect the enzyme production significantly and optimization methods could be effectively used for microbial enzyme production.

Disclosure statement: The author declared no conflicts of interest. The author alone is responsible for the content and writing of the paper.

Funding: This research received no specific grant from any funding agency in the public, commercial, or not-profit sectors.
Acknowledgements: All the experiments were done in the laboratories of High Technology Application and Research Centre (YUTAM), Erzurum Technical University, Erzurum, Turkey.

\section{References}

Aissa, I., Nimbarte, V.D., Zardi-Bergaoui, A., Znati, M., Flamini, G., Ascrizzi, R., \& Jannet, H.B. (2019). Isocostic Acid, a Promising Bioactive Agent from the Essential Oil of Inula viscosa (L.): Insights from Drug Likeness Properties, Molecular Docking and SAR Analysis. Chemistry Biodiversity, 16(4), e1800648. doi:10.1002/cbdv.201800648

Al-Dissi, N.M., Salhab, A.S., \& Al-Hajj, A.H. (2001). Effects of Inula viscosa leaf extracts on abortion and implantation in rats. Journal of Ethnopharmacology, 77(1), 117-121.

Al-Eisawi, D. (1998). Field Guide to Wild Flowers in Jordan and Neighboring Countries. Jordan Foundation Press, Amman, 97.

Al-Qura'n, S. (2009). Ethnopharmacological survey of wild medicinal plants in Showbak, Jordan. Journal of Ethnopharmacology, 123, 45-50.

Alhaddad, A.Y., Cabibihan, J.J., Hayek, A., \& Bonarini, A. (2019). Influence of the shape and mass of a small robot when thrown to a dummy human head. SN Applied Sciences, 1(11). doi:10.1007/s42452-019-1447-7

Ali-Shtayeh, M.S., Yaniv, Z. \& Mahajna, J. (2000). Ethnobotanical survey in the Palestinian area: a classification of the healing potential of medicinal plants. Journal of Ethnopharmacology, 73, 221-232. 
Alkofahi, A., \& Atta, A.H. (1999). Pharmacological screening of the antiulserogenic effects of some Jordanian medicinal plants in rats. Journal of Ethnopharmacology, 67, 341-345.

Amin, S., Kaloo, Z.A., Singh, S., \& Altaf, T. (2013). Medicinal Importance of Genus Inula- A Review. International Journal of Current Research and Review, 05, 20-26.

Aydogan, M.N., Taskin, M., Canli, O., Arslan, N.P., \& Ortucu, S. (2014). Tris-sucrose buffer system: a new specially designed medium for extracellular invertase production by immobilized cells of isolated yeast Cryptococcus laurentii MT-61. Folia Microbiologica (Praha), 59(1), 9-16. doi:10.1007/s12223-013-0258-2

Bar-Shalom, R., Bergman, M., Grossman, S., Azzam, N., Sharvit, L., \& Fares, F. (2019). Inula viscosa Extract Inhibits Growth of Colorectal Cancer Cells in vitro and in vivo Through Induction of Apoptosis. Frontiers in Oncology, 9, 227. doi:10.3389/fonc.2019.00227

Barbetti, P., Chiappini, I., Fardella, G., \& Menghini, A. (1985). A new eudesmane acid from Dittrichia (Inula) viscosa. Planta Medica, 51, 471.

Baytop, T. (1984). Therapy with Medicinal Plants in Turkey. Sanal Press, Istanbul, Turkey, 167pp.

Benbacer, L., Merghoub, N., El Btaouri, H., Gmouh, S., Attaleb, M., Morjani, H., Amzazi, S., \& El Mzibri, M. (2012). Antiproliferative effect and induction of apoptosis by Inula viscosa L. and Retama monosperma L. extracts in human cervical cancer cells, in: Rajamanickam. Topics on Cervical Cancer with an Advocacy for Prevention, InTech, Rijeka, Crotia, 267284

Beyranvand, F., Alizadeh, M., Shahsavari, S., Azarbaijani, K., Safarzadeh, A., Mohammadi, M. \& Sepahvand, A. (2018). A review of the most effective medicinal plants for dermatophytosis in traditional medicine. Biomedical Research and Therapy, 5(6), 2378-2388. doi:10.15419/bmrat.v5i6.450

Burkert, J.F.M., Kalil, S.J., Filho, F.M., \& Rodrigues, M.I., 2006. Parameters optimization for enzymatic assays using experimental design. Brazilian Journal of Chemical Engineering, 23, 163- 170.

Canli, O., \& Kurbanoglu, E.B. (2011). Utilization of ram horn peptone in the production of glucose oxidase by a local isolate Aspergillus niger OC-3. Preparative Biochemistry and Biotechnology, 41(1), 73-83. doi: $10.1080 / 10826068.2010 .534223$

Canli, O., \& Kurbanoglu, E.B. (2012). Application of low magnetic field on inulinase production by Geotrichum candidum under solid state fermentation using leek as substrate. Toxicology and Industrial Health, 28(10), 894-900. doi:10.1177/0748233711425079

Canli, O., Tasar, G.E., \& Taskin, M. (2013). Inulinase production by Geotrichum candidum OC-7 using migratory locusts as a new substrate and optimization process with Taguchi DOE. Toxicology and Industrial Health, 29(8), 704-710. doi:10.1177/0748233712442737

Chaturvedi, S., Bhattacharya, A., Nain, L., Prasanna, R., \& Khare, S.K. (2019). Valorization of agro-starchy wastes as substrates for oleaginous $\begin{array}{llll}\text { microbes. Biomass and } 127 . & \end{array}$ doi:10.1016/j.biombioe.2019.105294

Chen, H.Q., Chen, X.M., Li, Y., Wang, J., Jin, Z.Y., Xu, X.M., Zhao, J.W., Chen, T.X., \& Xie, Z.J. (2009). Purification and Characterisation of Exoand Endo-Inulinase From Aspergillus ficuum JNSP5-06. Food Chemistry, $115,1206-1212$

Chi, Z., Chi, Z., Zhang, T., Liu, G., \& Yue, L. (2009). Inulinase-expressing microorganisms and applications of inulinases. Applied Microbiology and Biotechnology, 82(2), 211-220. doi:10.1007/s00253-008-1827-1

Cohen, Y., Wang, W.Q., Ben-Daniel, B.-H., \& Ben-Daniel, Y. (2006). Extracts of Inula viscosa control downy mildew of grapes caused by Plasmopara viticola. Phytopathology, 96, 417-424.

Danino, O., Gottlieb, H.E., Grossman, S., \& Bergman, M. (2009). Antioxidant activity of 1, 3-dicaffeoylquinic acid isolated from Inula viscosa. Food Research International, 42, 1273-1280.

Deng, H., Bian, Z., Yang, F., Liu, S., Li, Z., Fan, Z., \& Tang, G. (2019). Use of autoclave extraction and liquid chromatography with tandem mass spectrometry for determination of maleic hydrazide residues in tobacco. Journal of Seperation Science, 42(14), 2390-2397. doi:10.1002/jssc. 201900250

Dor, E., \& Hershenhorn, J. (2012). Allelopathic effects of Inula viscosa leaf extracts on weeds. Allelopathy Journal, 30(2), 281-289.

Erdal, S., Canli, O., \& Algur, O.F. (2011). Inulinase production by Geotrichum candidum using Jerusalem artichoke. Romanian Biotechnological Letters, 16(4), 6375-6381.

Ertuğ, F. (2014). Illustrated Flora of Turkey. Etnobotanik, 1, 354.

Farid, M.A., Ghoneimy, E.A., El-Khawaga, M.A., Negm-Eldein, A., \& Awad, G.E.A. (2013). Statistical optimization of glucose oxidase production from Aspergillus niger NRC9 under submerged fermentation using response surface methodology. Annals of Microbiology, 63(2), 523-531. doi:10.1007/s13213-012-0497-5

Gokbulut, A., Ozhan, O., Satilmis, B., Batcioglu, K., Gunal, S., \& Sarer, E. (2013). Antioxidant and Antimicrobial Activities, and Phenolic Compounds of Selected Inula species from Turkey. Natural Product Communications, 8(4), 475-478.

Gueribis, F., Zermane, N., Khalfi-Habess, O., Siafa, A., Cimmino, A., Boari, A., \& Evidente, A. (2019). Bioefficacy of compounds from Dittrichia viscosa (Asteraceae) as protectant of chickpea seeds against the cowpea seed beetle Callosobruchus maculatus (Coleoptera: Chrysomelidae). Journal of Plant Diseases and Protection, 126(5), 437-446. doi:10.1007/s41348-019-00240-w

Jean, M.D., \& Tzeng, Y.F. (2013). Use of Taguchi Methods and Multiple Regression Analysis for Optimal Process Development of High Energy Electron Beam Case Hardening of Cast Iron. Surface Engineering, 19(2), 150-156. doi:10.1179/026708403225002496

Kalachaveedu, M., Raghavan, D., Telapolu, S., Kuruvilla, S., \& Kedike, B. (2018). Phytoestrogenic effect of Inula racemosa Hook f - A cardioprotective root drug in traditional medicine. Journal of Ethnopharmacology, 210, 408-416. doi:10.1016/j.jep.2017.09.001

Karim, F., Al-Okleh, A., Suleiman, S., \& Quraan, S. (1990). Poisonous Plants in Jordan. Jordan Natural History Museum, Irbid, Jordan.

Kıvak, T. (2014). Optimization of surface roughness and flank wear using the Taguchi method in milling of Hadfield steel with PVD and CVD coated inserts. Measurement, 19-28. doi:10.1016/j.measurement.2013.12.017

Lauro, L., \& Rolih, C. (1990). Observations and research on an extract of Inula viscosa. Bollettino Societa Italiana Biological Sperimentable, 66, 829834.

Mandal, A., Kar, S., Dutta, T., Pati, B.R., Mondal, K.C., \& Das Mohapatra P.K. (2015). Parametric optimization of submerged fermantation conditions for xylanase production by Bacillus cereus BSA1 through Taguchi Methodology. Acta Biologica Szegediensis, 59(2), 189-195.

Mangathayaru, K., Kuruvilla, S., Balakrishna, K., \& Venkhatesh, J. (2009). Modulatory effect of Inula racemosa Hook. f. (Asteraceae) on experimental atherosclerosis in guinea-pigs. Journal of Pharmacy and Pharmacology, 61(8), 1111-1118. doi:10.1211/jpp/61.08.0016

Miller, G.L. (1959). Use of dinitrosalicylic acid reagent for the determination of reducing sugar. Analytical Chemistry, 31, 426-428.

Mori, T. (2011). Taguchi methods: benefits, impacts, mathematics, statistics, and applications. ASME Press, New York.

Orhan, N., Gökbulut, A., \& Deliorman Orhan, D. (2017). Antioxidant potential and carbohydrate digestive enzyme inhibitory effects of five Inula species and their major compounds. South African Journal of Botany, 111, 86-92. doi:10.1016/j.sajb.2017.03.040

Ozkan, E.P.K., Yildirim, F.B., Tas, A., Eker, I., Yavuz, I., Ucar, M.Z., \& Turker, A. (2019). Promising medicinal plant Inula viscosa L.: Antiproliferative, antioxidant, antibacterial and phenolic profiles. Progress in Nutrition, 21(3), 652-661. doi:10.23751/pn.v21i3.7186

Passos, L.P., Vidigal, M.C., de Sousa, F.B., Barud, H.S., de Paiva, A.F.C., Verneque, R.D.S., \& Freitas, V.D.P. (2006). Autoclave-Assisted Acidic Extraction of Water-Soluble Carbohydrates in Forage Grasses. Communications in Soil Science and Plant Analysis, 37(11-12), 1731-1746. doi:10.1080/00103620600710496

Phadke, M.S. (1989). Quality Engineering Using Robust Design. Prentice Hall, Englewood Cliffs, New Jersey.

Rao, R.S., Kumar, C.G. Praksham, R.S., \& Hobbs, P.J. (2008). The Taguchi methodolgy as a statistical tool for biotechnological applications: a critical appraisal. Biotechnology Journal, 3(4), 510-523.

Seca, A.M., Grigore, A., Pinto, D.C., \& Silva, A.M. (2014). The genus Inula and their metabolites: from ethnopharmacological to medicinal uses. Journal of Ethnopharmacology, 154(2), 286-310. doi:10.1016/j.jep.2014.04.010

Sguarezi, C., Longo, C., Boni, G., Silva, M.F., Luccio, M.D., Mazutti, M.A., Maugeri, F., Rodrigues, M.I., \& Treichel, H. (2009). Inulinase production by agro-industrial residues: Optimization of pretreatment of substrates and production medium. Food Bioprocess Technology, 2, 409-414.

Sharma, A.D., Kainth, S., \& Gill, P.K. (2006). Inulinase production using garlic ( Allium sativum ) powder as a potential substrate in Streptomyces sp. Journal of Food Engineering, 77(3), 486-491. doi:10.1016/j.jfoodeng.2005.06.072

Sharma, P., Verma, A., Sidhu, R.K., \& Pandey, O.P. (2005). Process parameter selection for strontium ferrite sintered magnets using Taguchi L9 orthogonal design. Journal of Materials Processing Technology, $168,147-151$ 
Sharma, P., Verma, A., Sidhu, R.K., \& Pandey, O.P. (2006). Effects of processing parameters on the magnetic properties of strontium ferrite sintered magnets using Taguchi orthohonal array design. Journal of Magnetism and Magnetic Materials, 307, 157-164.

Singh, R.S., Chauhan, K., Kaur, K., \& Pandey, A. (2020). Statistical optimization of solid-state fermentation for the production of fungal inulinase from apple pomace. Bioresource Technology Reports, 9. doi:10.1016/j.biteb.2019.100364

Singh, R.S., Dhaliwal, R., \& Puri, M. (2006). Production of Inulinase from Kluyveromyces marxianus YS-1 Using Root Extract of Asparagus racemosus. Process Biochemistry, 41, 1703-1707.

Tan, O., Zaimoglu, A.S., Hinislioglu, S., \& Altun, S. (2005). Taguchi approac for optimization of the belleding on cement-based grouts. Tunnelling and Underground Space Technology, 20, 167-173.

Tasar, O.C. (2017). Enhanced $\beta$-fructofuranosidase biosynthesis by Rhodotorula glutinis using Taguchi robust design method. Biocatalysis $\begin{array}{lll}\text { and Biotransformation, 35(3), 191-196. } & \end{array}$ doi:10.1080/10242422.2017.1304386

Tasar, O.C., Erdal, S., \& Algur, O.F. (2015). Utilization of Leek (Allium ampeloprasum var. porrum) for inulinase production. Preparative Biochemistry and Biotechnology, 45(6), 596-604. doi:10.1080/10826068.2014.940538

Taskin, M., Erdal, S., \& Canli, O. (2010). Utilization of waste loquat (Eriobotrya Japonica Lindley) kernels as substrate for scleroglucan production by locally isolated Sclerotium rolfsii. Food Science and Biotechnology, 19(4), 1069-1075. doi:10.1007/s10068-010-0150-7

Taskin, M., Esim, N., Genisel, M., Ortucu, S., Hasenekoglu, I., Canli, O., \& Erdal, S. (2013). Enhancement of invertase production by Aspergillus niger OZ-3 using low-intensity static magnetic fields. Preparative Biochemistry and Biotechnology, 43, 177-188.

Taskin, M., Ortucu, S., Unver, Y., Tasar, O.C., Ozdemir, M., \& Kaymak, H. C. (2016). Invertase production and molasses decolourization by coldadapted filamentous fungus Cladosporium herbarum ER-25 in nonsterile molasses medium. Process Safety and Environmental Protection, 103, 136-143. doi:10.1016/j.psep.2016.07.006

Xiong, C., Jinhua, W., \& Dongsheng, L. (2007). Optimization of solid-state medium for the production of inulinase by Kluyveromyces S120 using response surface methodology. Biochemical Engineering Journal, 34(2), 179-184. doi:10.1016/j.bej.2006.12.012

Zeggwagh, N.A., Ouahidi, M.L., Lemhadri, A., \& Eddouks, M. (2006). Study of hypoglycaemic and hypolipidemic effects of Inula viscosa L. aqueous extract in normal and diabetic rats. Journal of Ethnopharmacology, 108(2), 223-227. doi:10.1016/j.jep.2006.05.005 